\title{
Correction to: Cell cycle inhibitors improve seed storability after priming treatments
}

\author{
Naoto Sano ${ }^{1,2} \cdot$ Mitsunori Seo $^{1}$
}

Published online: 25 April 2020

(c) The Author(s) 2020

\section{Correction to: \\ Journal of Plant Research (2019) 132:263-271 https://doi.org/10.1007/s10265-018-01084-5}

The article Cell cycle inhibitors improve seed storability after priming treatments, written by Naoto Sano and Mitsunori Seo, was originally published Online First without Open Access. After publication in volume 132, issue 2, page 263-271 the author decided to opt for Open Choice and to make the article an Open Access publication. Therefore, the copyright of the article has been changed to $($ ) The Author(s) 2020 and the article is forthwith distributed under the terms of the Creative Commons Attribution 4.0 International License (https://creativecommons.org/licenses/by/4.0/), which permits use, duplication, adaptation, distribution and reproduction in any medium or format, as long as you give appropriate credit to the original author(s) and the source, provide a link to the Creative Commons license, and indicate if changes were made.

The original article was updated.

Open Access This article is licensed under a Creative Commons Attribution 4.0 International License, which permits use, sharing, adaptation, distribution and reproduction in any medium or format, as long as you give appropriate credit to the original author(s) and the source, provide a link to the Creative Commons licence, and indicate if changes were made. The images or other third party material in this article are included in the article's Creative Commons licence, unless indicated otherwise in a credit line to the material. If material is not included in

The original article can be found online at https://doi.org/10.1007/ s10265-018-01084-5.

Mitsunori Seo

mitsunori.seo@riken.jp

1 RIKEN Center for Sustainable Resource Science, 1-7-22 Suehiro-cho, Tsurumi-ku, Yokohama, Kanagawa 230-0045, Japan

2 Present Address: Institut Jean-Pierre Bourgin, INRA, AgroParisTech, CNRS, Université Paris-Saclay, 78000 Versailles, France the article's Creative Commons licence and your intended use is not permitted by statutory regulation or exceeds the permitted use, you will need to obtain permission directly from the copyright holder. To view a copy of this licence, visit http://creativecommons.org/licenses/by/4.0/.

Publisher's Note Springer Nature remains neutral with regard to jurisdictional claims in published maps and institutional affiliations. 